\title{
Pengaruh Rasio Tepung Ampas Tahu dan Kacang Hijau Serta Persentase Substitusi Tepung Terigu Terhadap Mutu Cookies
}

\author{
(The Influence of the Ratio of Dreg Tofu and Mung Bean Flour and Percentage of
} Substitution of Wheat Flour Toward Cookies Quality)

\author{
Muhammad Fadhil ${ }^{1}$, Martunis ${ }^{1}$, Anshar Patria $^{1 *}$ \\ ${ }^{1}$ Program Studi Teknologi Hasil Pertanian, Fakultas Pertanian, Universitas Syiah Kuala
}

\begin{abstract}
Abstrak. Cookies merupakan kue kering yang dibuat dari adonan yang lunak, berkadar lemak tinggi, bertekstur renyah dan kurang padat. Penelitian ini bertujuan untuk mengetahui pengaruh rasio tepung ampas tahu dan kacang hijau serta substitusi tepung terigu terhadap mutu kimia, dan nilai organoleptiknya. Penelitian ini dilakukan menggunakan Rancangan Acak Lengkap (RAL) yang terdiri dari 2 faktor, yaitu faktor pertama rasio tepung ampas tahu dan kacang hijau $(\mathrm{K})$ yang terdiri dari 3 taraf yaitu $(\mathrm{K} 1=70 \%: 30 \%, \mathrm{~K} 2=50 \%: 50 \%$, $\mathrm{K} 3=$ 30\%:70\%). Faktor kedua yaitu substitusi tepung terigu (T) yang terdiri dari 3 taraf yaitu $(\mathrm{T} 1=25 \%, \mathrm{~T} 2=50 \%$, $\mathrm{T} 3=75 \%$ ). Dengan demikian terdapat 9 kombinasi perlakuan dengan jumlah ulangan sebanyak 3 kali, sehingga diperoleh 27 satuan percobaan. Hasil penelitian diperoleh perlakuan terbaik berdasarkan nilai proksimat yaitu kadar air 4,12\%, kadar abu 2,04\%, kadar lemak 27,27\%, kadar protein 22,11\%, kadar karbohidrat (by difference) 44,47\%, nilai organoleptik warna 3,40 (biasa), aroma 3,49 (biasa), rasa 3,56 (suka) dan tekstur 2,88 (biasa). Perlakuan terbaik selanjutnya dianalisis kadar serat $(3,66 \%)$.
\end{abstract}

Kata Kunci: Cookies, tepung ampas tahu, tepung kacang hijau, tepung terigu.

Abstract. Cookies are made from a soft dough containing high fat, has crisp and less dense texture. This research aims to know the influence of the ratio of flour from dregs of tofu and mung beans with wheat flour substitution against the chemical quality, and the organoleptic value. This research was conducted using a Randomized Complete Design (RCD) consisting of two factors. The first factor was the ratio between mung bean flour and tofu dregs flour $(K)$ consisting of 3 levels $(K 1=70 \%: 30 \%, K 2=50 \%: 50 \%, K 3=30 \%: 70 \%)$. The second factor was wheat flour substitution $(T)$ consisting of 3 levels $(T 1=T 2=25 \%, 50 \%, T 3=75 \%)$. Thus there were nine combination treatment with three times repetition resulting 27 experimental units. The results showed that the best treatment based on the proximate analysis had the following characteristics: $4.12 \%$ water content, $2.04 \%$ ash content, $27.27 \%$ fat content, $22.11 \%$ protein content, carbohydrate content (by difference) $44.47 \%$, color organoleptic value 3.40 (netral), aroma 3.49 (netral), taste 3.56 (like) and texture 2.88 (netral) Moreover, the treatment with the best result were analyzed for fiber content (3.66\%).

Keywords: Cookies, dreg tofu flour, mung bean flour, wheat flour.

\section{PENDAHULUAN}

Menurut SNI 01-2973- (2011), cookies merupakan kue kering yang dibuat dari adonan yang lunak, berkadar lemak tinggi, bertekstur renyah dan kurang padat. Selama ini, bahan utama pembuatan cookies yaitu tepung terigu. Tepung terigu merupakan tepung atau bubuk yang berasal dari biji gandum, keisimewaan tepung terigu adalah kemampuan membentuk guten yang bersifat elastis pada saat dibasahi dengan air. Sifat elastis pada gluten ini membuat kue tidak mudah rusak ketika dicetak (Wahyuni, 2006). Pada umumnya pembuatan cookies hanya dihasilkan dengan tanpa adanya substitusi bahan lain yang dapat meningkatkan nilai gizi. Oleh karena itu, perlu dikembangkan suatu alternatif yang dapat meningkatkan mutu fisik dan kimia dengan cara mengkombinasikan pembuatan cookies dengan penambahan tepung ampas tahu dan kacang hijau cookies pangan fungsional yang baik untuk tubuh.

Ampas tahu merupakan hasil samping dalam proses pembuatan tahu. Umumnya masyarakat menganggap ampas tahu sebagai limbah hasil pertanian yang bernilai ekonomis rendah. Pemanfaatan ampas tahu sebagai bahan pangan masih rendah. Salah satu cara mengolah ampas tahu yaitu dengan menjadikan ampas tahu menjadi tepung sehingga lebih

Corresponding author: Anshar.patria@unsyiah.ac.id

JIM Pertanian - THP, Vol. 4, No. 1, Februari 2019: 517-526 
mudah untuk dicampur dan atau disubstitusi pada pembuatan produk pangan (Setiawan, 2011).

Tepung kacang hijau adalah tepung yang diolah dari kacang hijau (Phaseolus radiatus L.) yang sudah dihilangkan kulit arinya dan telah diolah menjadi tepung. Tepung Kacang hijau memiliki kandungan protein, kerbohidrat dan serat yang tinggi dan juga merupakan sumber mineral penting, antara lain kalsium dan fosfor. Sedangkan kandungan lemaknya merupakan asam lemak tak jenuh (Cahyono, 2008). Penelitian ini akan mempelajari tentang pengaruh rasio tepung ampas tahu dan kacang hijau san substitusi tepung terigu terhadap mutu cookies. Pembuatan cookies dengan menggunakan tepung ampas tahu dan kacang hijau diharapkan dapat menjadi salah satu cara dalam menjaga kesehatan tubuh serta dapat dikonsumsi oleh semua kalangan

\section{METODE PENELITIAN}

Penelitian ini telah dilakukan pada bulan Juli sampai Agustus 2017 di Laboratorium Rekayasa Proses Pangan dan Industri, Laboratorium Analisis Pangan dan Hasil Pertanian, Laboratorium Uji Sensori. Jurusan Teknologi Hasil Pertanian, Fakultas Pertanian, Universitas Syiah Kuala, Banda Aceh

\section{Bahan dan Alat}

Bahan yang digunakan dalam penelitian ini adalah tepung ampas tahu, tepung kacang hijau, tepung terigu, gula halus, margarin, mentega, susu skim, kuning telur, soda kue. Sedangkan bahan yang digunakan dalam analisis adalah dietil eter, $\mathrm{HCl}, \mathrm{H}_{2} \mathrm{SO}_{4}, \mathrm{~K}_{2} \mathrm{SO}_{4}, \mathrm{H}_{\mathrm{g}} \mathrm{O}$, $\mathrm{NaOH}$, ethanol dan $\mathrm{H}_{3} \mathrm{BO}_{3}$. Alat yang digunakan dalam pembuatan cookies adalah baskom, pisau, blender, timbangan analitik, oven, loyang, sendok, mixer, panci, penganduk. Sedangkan alat yang digunakan untuk analisis adalah oven yang dilengkapi dengan blower, desikator, erlenmayer, cawan porselen, penjepit cawan, gelas ukur, hydrolic press, pipet tetes, timbangan analitik, kertas saring, labu kjeldhal, soxhlet.

\section{Rancangan Penelitian}

Penelitian ini dilakukan menggunakan Rancangan Acak Lengkap (RAL) yang terdiri dari 2 faktor, yaitu faktor (K) rasio tepung kacang hijau dan kacang yang terdiri dari 3 taraf yaitu $(\mathrm{K} 1=70 \%: 30, \mathrm{~K} 2=50 \%: 50 \%, \mathrm{~B} 3=30 \%: 70 \%)$. Faktor kedua yaitu substitusi tepung terigu $(\mathrm{T})$ yang terdiri dari 3 taraf yaitu $(\mathrm{T} 1=25 \%, \mathrm{~T} 2=50 \%, \mathrm{~K} 3=75 \%)$. Dengan demikian terdapat 9 kombinasi perlakuan dengan jumlah ulangan sebanyak 3 kali, sehingga diperoleh 27 satuan percobaan.

\section{Analisis Data}

Untuk menguji pengaruh dari setiap faktor dan interaksi antar faktor terhadap parameter analisis, dilakukan analisis statistik dengan menggunakan ANOVA (Analysis of varians) apabila perlakuan yang diberikan menunjukkan pengaruh nyata terhadap parameter yang diuji, maka dilakukan uji lanjut BNT (Beda Nyata Terkecil).

\section{Prosedur Penelitian}

Penelitian ini terdiri atas dua tahapan penelitian, yang pertama adalah tahapan pembuatan tepung ampas tahu dan prosedur pembuatan cookies. Pembuatan tepung ampas tahu dilakukan

Pengaruh Rasio Tepung Ampas Tahu dan Kacang Hijau serta Substitusi Tepung Terigu terhadap Mutu Cookies (Muhammad Fadhil, Martunis dan Anshar Patria)

Jurnal Ilmiah Mahasiswa Pertanian, Vol. 4, No. 1, Februari 2019: 517-526 
dengan pencucian dan pembilasan $3 \mathrm{kali}$, pengepresan dengan hidrolic press, pengovenan, penggilingan dan pengayakan ukuran 80 mesh. Pembuatan cookies dilakukan dengan menimbang Lemak 23\% (mentega 80\% : margarin 20\%), gula halus (23\%) dan kuning telur $(2,3 \%)$ dari total berat adonan $436 \mathrm{~g}$, kemudian diaduk dengan menggunakan mixer $\pm 7-10$ menit hingga membentuk krim. Selanjutnya ditambahkan tepung sebanyak $46 \%=200 \mathrm{~g}$ (tepung ampas tahu dan tepung kacang hijau dengan perbandingan $70 \%-30 \%, 50 \%-50 \%$, $30 \%-70 \%)$ dari substitusi tepung terigu $(25 \%, 50 \%, 75 \%)$, dan soda kue $(0,4 \%)$ dicampur hingga membentuk adonan dengan menggunakan mixer \pm 5 menit. Adonan dicetak dengan berat 5 gram dan tinggi $0.5 \mathrm{~cm}$ menggunakan sendok di atas Loyang. Adonan yang telah dicetak, dipanggang dalam oven pada suhu $165^{\circ} \mathrm{C}$ selama 25 menit.

\section{Kadar Air}

\section{HASIL DAN PEMBAHASAN}

Analisis kadar air dilakukan untuk mengetahui kandungan air yang terdapat pada cookies ampas tahu dan tepung kacang hijau. Hasil menunjukkan kadar air berkisar antara $4,12 \%-4,78 \%$, dengan rata-rata 4,47 \%. Hasil analisis sidik ragam menunjukan bahwa rasio tepung ampas tahu dan tepung kacang hijau $(\mathrm{K})$, serta subtitusi tepung terigu $(\mathrm{T})$ dan interaksi antara rasio tepung ampas tahu dan kacang hijau serta subtitusi tepung terigu (KT) berpengaruh tidak nyata $(\mathrm{P}>0,05)$ terhadap kadar air cookies ampas tahu dan tepung kacang hijau.

\section{Kadar Abu}

Kadar abu merupakan parameter untuk menunjukkan nilai kandungan bahan anorganik (mineral) yang ada di dalam suatu bahan atau produk (Roni, 2008 di dalam Khuzrian 2011). Hasil analisis kadar abu cookies ampas tahu dan tepung kacang hijau berkisar antara $1,82 \%$ - 2,60\% dengan nilai rata-rata 2,32\% .

Hasil analisis sidik ragam menunjukkan bahwa rasio tepung ampas tahu dan tepung kacang hijau $(\mathrm{K})$ berpengaruh sangat nyata $(\mathrm{P}<0.01)$ terhadap kadar abu cookies. Sedangkan subtitusi tepung terigu $(\mathrm{T})$ dan interaksi keduanya $(\mathrm{KT})$ berpengaruh tidak nyata $(\mathrm{P}>0.05)$ terhadap kadar abu cookies. Pengaruh rasio tepung ampas tahu dan kacang hijau dapat dilihat pada Gambar 1.

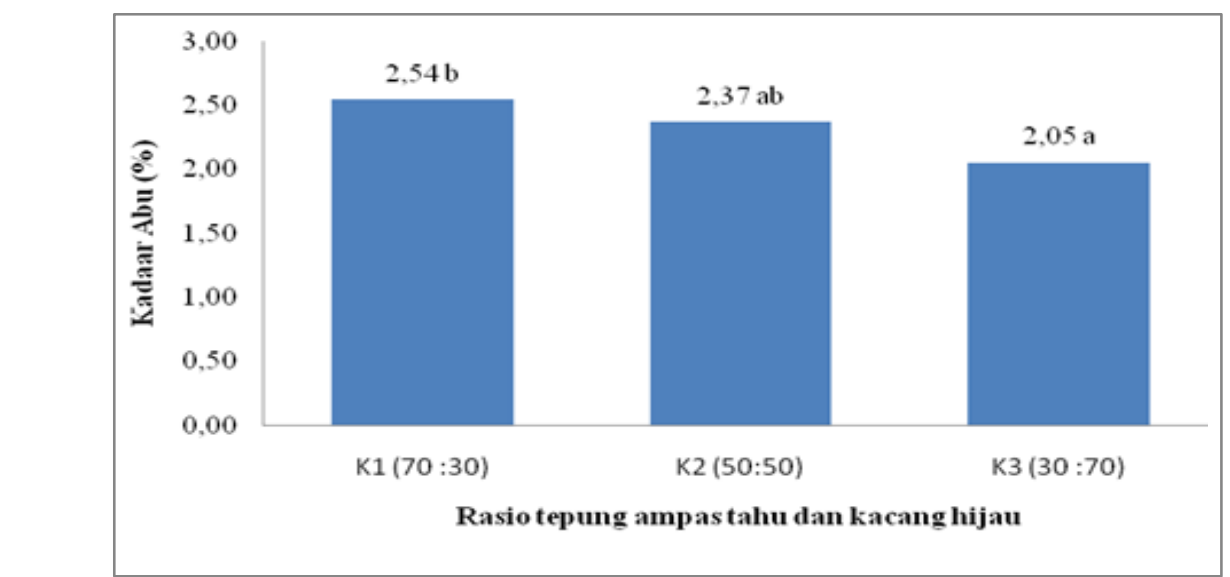

Gambar 1. Pengaruh rasio tepung ampas tahu dan tepung kacang hijau (K) terhadap kadar abu cookies ampas tahu dan tepung kacang hijau (Nilai-nilai yang diikuti oleh huruf yang sama menunjukkan perbedaan yang tidak nyata pada $\mathrm{BNT}_{0,01}=0,48, \mathrm{KK}=8,81$ ).

Pengaruh Rasio Tepung Ampas Tahu dan Kacang Hijau serta Substitusi Tepung Terigu terhadap Mutu Cookies (Muhammad Fadhil, Martunis dan Anshar Patria)

Jurnal Ilmiah Mahasiswa Pertanian, Vol. 4, No. 1, Februari 2019: 517-526 
Berdasarkan uji $\mathrm{BNT}_{0,01}$ (Gambar 1), rasio tepung ampas tahu dan kacang hijau (K1) menghasilkan kadar abu cookies tertinggi yaitu 2,54\%, dan tidak berbeda dengan rasio tepung ampas tahu dan kacang hijau (K2) yaitu 2,37\%, namun berbeda nyata dengan perlakuan rasio tepung ampas tahu dan kacang hijau (K3) yaitu 2,05\%. Nilai kadar abu berdasarkan syarat mutu SNI adalah 1,5\%. Namun cookies tepung ampas tahu dan tepung kacang hijau yang dihasilkan melebihi dari syarat mutu SNI. Hal ini dikarenakan tingginya kandungan mineral pada tepung ampas tahu dan tepung kacang hijau. Menurut Ismanto (2013), apabila semakin banyak tepung ampas tahu yang dicampurkan maka kandungan kadar abu akan semakin meningkat. Hal ini disebabkan oleh kandungan mineral tepung ampas tahu lebih tinggi dibandingkan dengan tepung kacang hijau.

\section{Kadar Protein}

Kadar protein cookies ampas tahu dan kacang hijau, kadar protein berkisar antara $20,06 \%$ - 22,24\% dengan rata-rata 20,82 \%. Hasil sidik ragam kadar protein cookies ampas tahu dan kacang hijau menunjukan bahwa rasio tepung ampas tahu dan kacang hijau (K) berpengaruh sangat nyata $(\mathrm{P}<0,01)$. Sedangkan subtitusi tepung terigu $(\mathrm{T})$ serta interaksi keduanya (KT) tidak berpengaruh nyata pada $(\mathrm{P}>0.05)$ terhadap cookies ampas tahu dan kacang hijau yang di hasilkan. Pengaruh rasio tepung ampas tahu dan kacang hijau dapat dilihat pada Gambar 2.

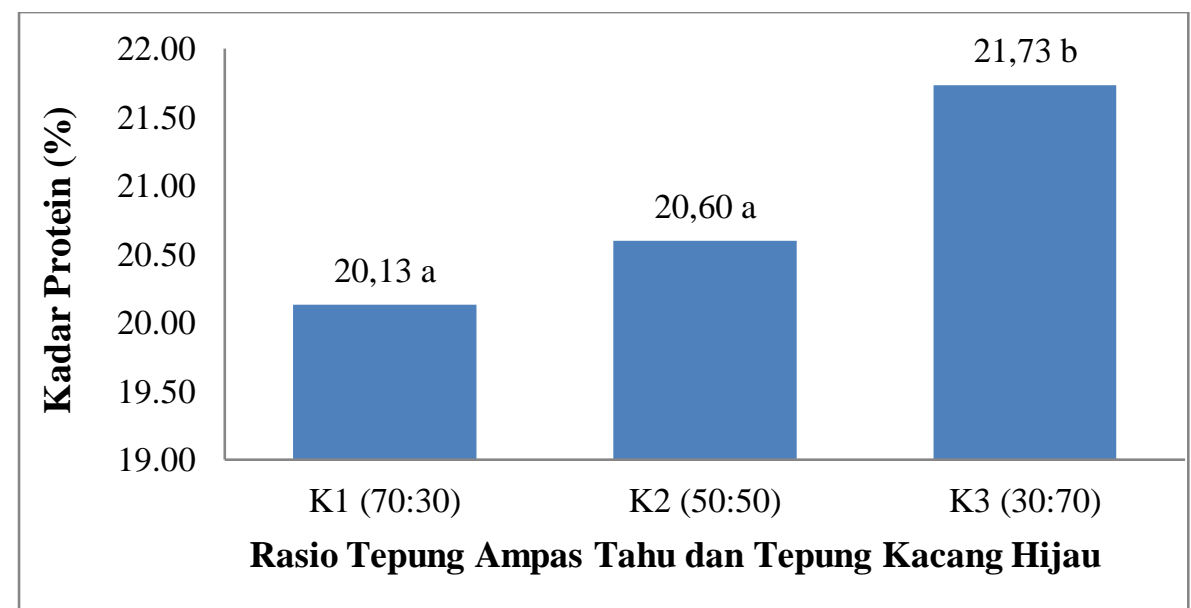

Gambar 2. Pengaruh rasio tepung ampas tahu dan kacang hijau (K) terhadap kadar protein (nilai-nilai yang diikuti oleh huruf yang sama menunjukan perbedaan yang tidak nyata pada uji $\mathrm{BNT}_{0,001}$ $=1,50, \mathrm{KK}=3,07 \%$ ).

Berdasarkan uji lanjut $\mathrm{BNT}_{0,01}$ (Gambar 2) menunjukkan bahwa kadar protein tertinggi cookies terdapat pada rasio tepung ampas tahu dan kacang hijau K1 (30\%-70\%) yaitu $21,73 \%$, yang berbeda nyata dengan rasio tepung ampas tahu dan kacang hijau K2 (50\%:50\%) yaitu 20,60\%, dan rasio tepung ampas tahu dan kacang hijau K3 (70\%-30\%) yaitu $20,13 \%$. Hal ini diduga karena kadar protein yang terkandung dalam cookies dipengaruhi oleh jenis tepung yang digunakan. Tepung yang digunakan ialah tepung ampas tahu dan tepung kacang hijau yang memiliki kandungan protein yang tinggi. Menurut Wati (2013), tepung ampas tahu memiliki kadar protein sebesar $17,72 \%$, sedangkan tepung kacang hijau kadar protein sebesar $32,2 \%$. Oleh karena itu, semakin tinggi jumlah tepung kacang hijau yang digunakan maka nilai kadar protein cookies yang dihasilkan akan semakin meningkat.

Pengaruh Rasio Tepung Ampas Tahu dan Kacang Hijau serta Substitusi Tepung Terigu terhadap Mutu Cookies (Muhammad Fadhil, Martunis dan Anshar Patria)

Jurnal Ilmiah Mahasiswa Pertanian, Vol. 4, No. 1, Februari 2019: 517-526 


\section{Kadar Lemak}

Kadar lemak terhadap cookies ampas tahu dan tepung kacang hijau berkisar antara $26,58 \%$ - 34,03\% dengan rata-rata 28,87\%. Hasil sidik ragam kadar lemak menunjukan bahwa rasio tepung ampas tahu dan tepung kacang hijau (K), subtitusi tepung terigu $(\mathrm{T})$ serta interaksi keduanya berpengaruh sangat nyata $(\mathrm{P}<0.01)$ terhadap kadar lemak cookies yang di hasilkan. Pengaruh rasio tepung ampas tahu dan tepung kacang hijau (K) dan subtitusi tepung terigu (T) serta interaksi keduanya dapat dilihat pada Gambar 3.

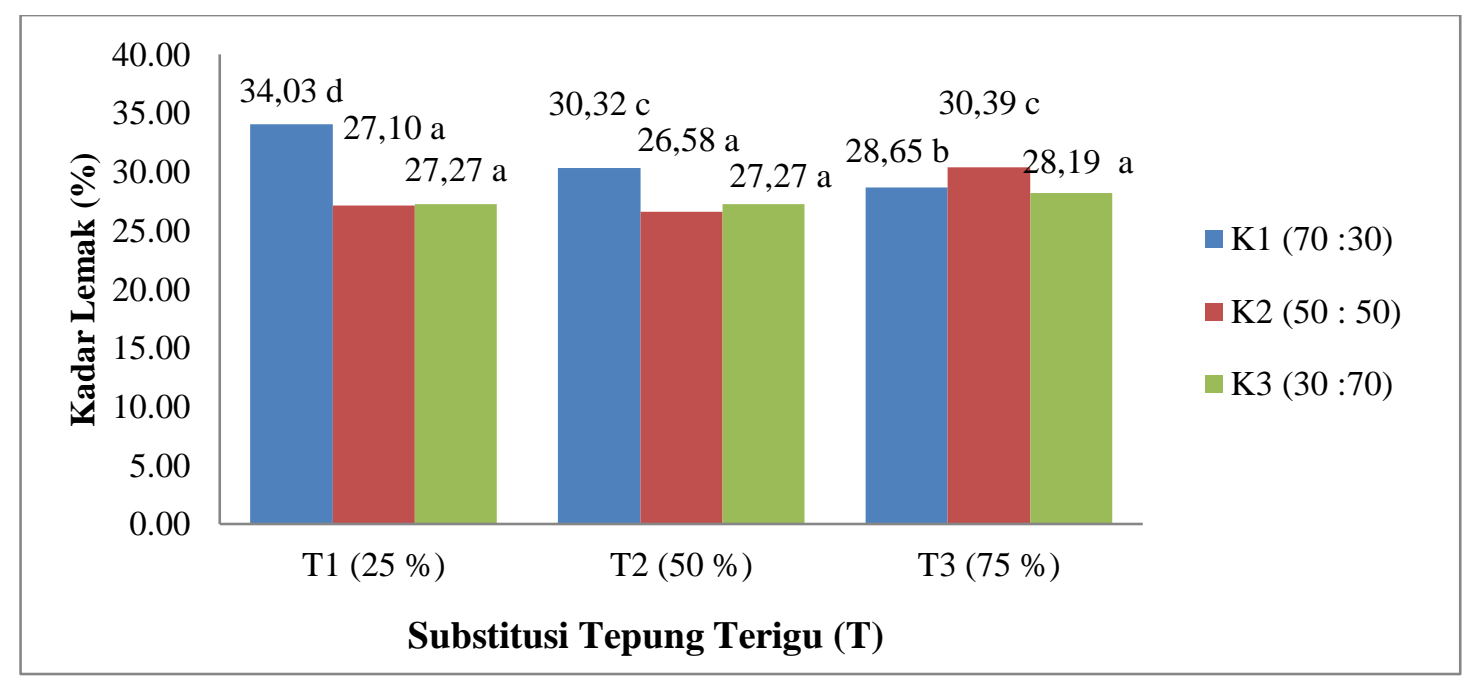

Gambar 3. Pengaruh interaksi antara rasio tepung ampas tahu dan tep ung kacang hijau (K) dan subtitusi tepung terigu(T) serta interaksi keduanya (KT)terhadap kadar lemak (nilai - nilai yang diikuti oleh huruf yang sama menunjukan perbadaan tidak nyata Pada uji BNT $\mathrm{KT}_{0,01}=1,45, \mathrm{KK}=2,14 \%$ ).

Berdasarkan Uji $\mathrm{BNT}_{0,01}$ (Gambar 3), menunjukkan bahwa cookies yang memiliki kandungan lemak tertinggi didapat pada perlakuan K1T1 (Rasio tepung ampas tahu dan tepung kacang hijau (70\% : 30\%) dengan subtitusi tepung terigu (25\%) yaitu sebesar 34,03\%, yang berbeda nyata seluruh perlakuan lainnya. Perbedaan kadar lemak yang dihasilkan diduga dipengaruhi oleh jenis tepung dan bahan tambahan yang digunakan. Menurut daftar komposisi bahan makanan (1995) tepung ampas tahu memiliki kandungan lemak lebih tinggi $(5,9 \mathrm{~g})$, tepung kacang hijau $(1,2 \mathrm{~g})$ dan terigu $(1 \mathrm{~g})$. Kandungan lemak yang dihasilkan cookies sudah memenuhi kadar SNI yaitu minimum 9,5\%. Kandungan lemak yang tinggi dimiliki oleh tepung ampas tahu sehingga perlakuan K1T1 yang menggunakan jumlah ampas tahu paling tinggi menghasilkan cookies dengan kadar lemak tertinggi. Hasil yang sama juga diperoleh dari penelitian Isyanti dan Lestari (2014), dimana opak yang menggunakan substitusi tepung ampas tahu memiliki kadar lemak yang lebih tinggi dari pada opak tanpa penambahan tepung ampas tahu.

\section{Kadar Karbohidrat (by difference)}

Karbohidrat merupakan sumber energi utama bagi manusia. Di negara-negara sedang berkembang salah satu indonesia, kurang lebih $80 \%$ energi makanan berasal dari karbohidrat (Almatsier, 2002). Berdasarkan hasil analisis kadar karbohidrat cookies ampas tahu dan tepung kacang hijau berkisar antara 37,24\% - 45,62\%, dengan rata-rata 42,57\%. Berdasarkan hasil analisis kadar karbohidrat cookies ampas tahu dan tepung kacang hijau berkisar antara $38,89 \%$ - 45,79\%, dengan rata-rata 43,53\%. Hasil sidik ragam kadar karbohidrat

Pengaruh Rasio Tepung Ampas Tahu dan Kacang Hijau serta Substitusi Tepung Terigu terhadap Mutu Cookies (Muhammad Fadhil, Martunis dan Anshar Patria)

Jurnal Ilmiah Mahasiswa Pertanian, Vol. 4, No. 1, Februari 2019: 517-526 
menunjukkan bahwa subtitusi tepung terigu $(\mathrm{T})$ berpengaruh tidak nyata $(\mathrm{P}>0.05)$ terhadap kadar karbohidrat yang dihasilkan. Sedangkan rasio tepung ampas tahu dan tepung kacang hijau $(\mathrm{K})$ serta interaksi keduanya $(\mathrm{KT})$ berpengaruh sangat nyata $(\mathrm{P}<0.01)$ terhadap terhadap kadar karbohidrat cookies yang dihasilkan. Pengaruh rasio tepung ampas tahu dan tepung kacang hijau (K) serta interaksi keduanya dapat dilihat pada Gambar 4.

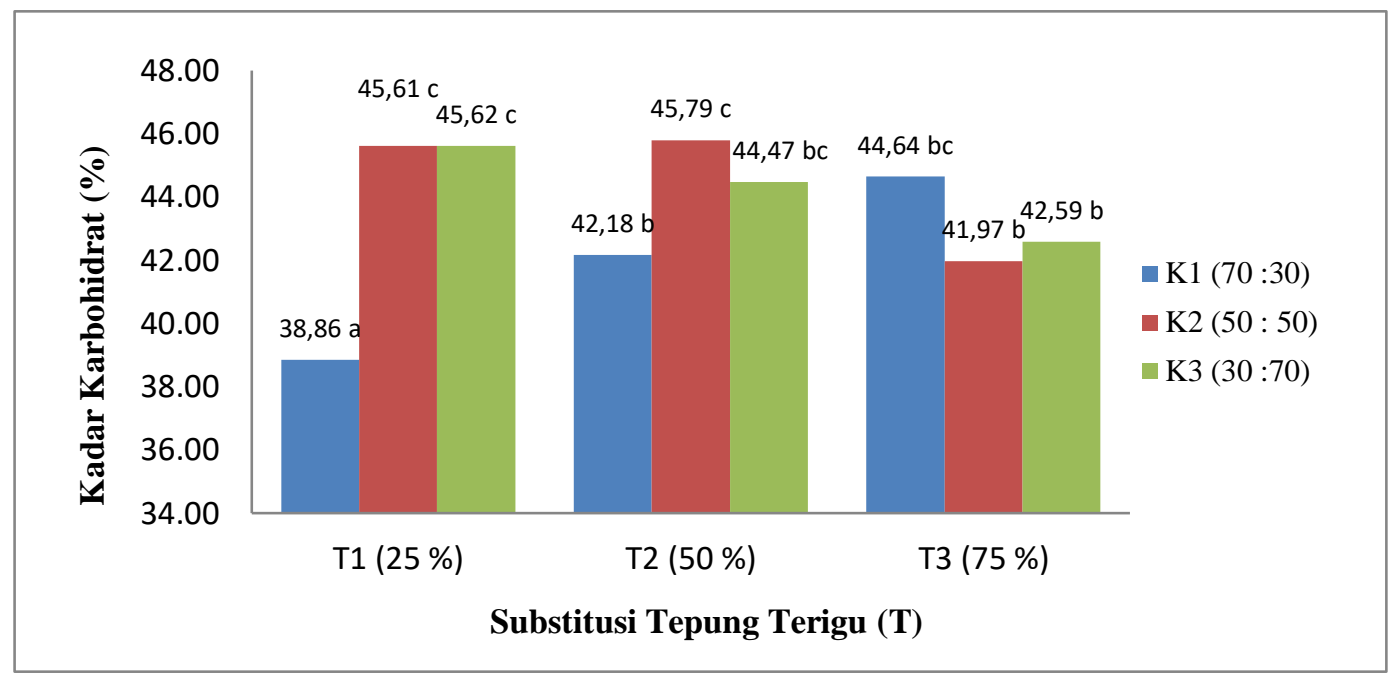

Gambar 4. Pengaruh interaksi antara rasio tepung ampas tahu dan tepung kacang hijau (K) serta interaksi keduanya (KT) terhadap kadar karbohidrat (nilai-nilai yang diikuti oleh huruf yang sama menunjukan perbadaan tidak nyata pada uji BNT $0,01=2,11, \mathrm{KK}=2,07 \%$ ).

Berdasarkan Uji $\mathrm{BNT}_{0,01}$ (Gambar 4), menunjukkan bahwa cookies yang memiliki kandungan karbohidrat tertinggi didapat pada perlakuan K2T2 (Rasio tepung ampas tahu dan tepung kacang hijau (50\% : 50\%) dengan subtitusi tepung terigu (50\%) yaitu 45,79\%, sedangkan kadar karbohidrat terrendah terdapat pada pelakuan K1 (70\%-30\%) dengan T1 (25\%). Menurut Andarwulan dkk., (2011) karbohidrat mengandung gula-gula pereduksi yang berperan dalam reaksi pencoklatan non enzimatis (millard) bila bereaksi dengan senyawa yang memiliki gugus amino seperti protein. Selama proses pemanggangan dapat terjadi kerusakan yang dapat menurunkan karbohidrat akibat terjadi reaksi millard.

Kadar karbohidrat yang diperoleh tidak sesuai dengan (SNI 01-2973:2011) yaitu minimum $70 \%$. Nilai kadar karbohidrat yang diperoleh lebih rendah dibandingkan dengan kadar karbohidrat cookies ampas tahu dan tapioka pada penelitian Khalid (2010), yaitu dengan kisaran antara 54,98 - 64,17\% dengan rataan 58,42\%. Hal ini diduga disebabkan penggunaan tepung yang bervariasi dan juga komposisi nilai gizi bahan yang berbeda.

\section{Uji Organoleptik Secara Hedonik}

Uji hedonik dilakukan dengan tujuan untuk mengetahui tingkat kesukaan panelis terhadap cookies bayam merah yang dihasilkan. Uji ini dilakukan oleh 25 orang panelis semi terlatih. Parameter yang diuji meliputi warna, rasa, aroma, tekstur. Penelitian ini menggunakan uji hedonik dengan skala 1 sampai dengan 5, dengan keterangan sebagai berikut : 1 = tidak suka, 2 = kurang suka, 3 = biasa, 4 = suka, $5=$ sangat suka. 


\section{Warna}

Warna merupakan salah satu pengukuran secara langsung pada suatu produk dengan menggunakan alat indra manusia sebagai alat ukurnya. Berdasarkan data hasil analisis terhadap uji organoleptik warna cookies ampas tahu dan tepung Kacang Hijau. Nilai untuk warna cookies ampas tahu dan tepung kacang hijau berkisar antara 2,99 (biasa)-3,40 (biasa) dengan rata-rata 3,17 (Biasa). Penilaian tersebut menunjukkan bahwa secara umum produk cookies ampas tahu dan tepung kacang hijau diterima oleh panelis. Hasil sidik ragam menunjukkan bahwa rasio tepung ampas tahu dan kacang hijau (K), dan Substitusi tepung terigu $(\mathrm{T})$ serta interaksi antara keduanya $(\mathrm{KT})$ berpengaruh tidak nyata $(\mathrm{P}>0,05)$ terhadap nilai organoleptik warna cookies tepung ampas tahu dan kacang hijau yang dihasilka. Hal ini dikarenakan tidak adanya perubahan warna pada cookies tepung ampas tahu dan kacang hijau yang dihasilkan.

\section{Aroma}

Aroma merupakan salah satu parameter dalam penentuan kualitas suatu produk makanan. Aroma yang khas dapat dirasakan oleh indera penciuman tergantung dari bahan penyusun dan bahan yang ditambahkan pada makanan. Data hasil pengamatan terhadap uji kesukaan aroma cookies ampas tahu dan tepung kacang hijau dapat dilihat pada. Nilai organoleptik cookies ampas tahu dan kacang hijau berkisar antara 2,93 (biasa) - 3,49 (biasa) dengan rata-rata 3,11 (biasa). Hasil sidik ragam menunjukkan bahwa rasio tepung ampas tahu dan kacang hijau (K), substitusi tepung terigu (T) dan interaksi antara keduanya (KT) tidak berpengaruh nyata $(\mathrm{P}>0,05)$ terhadap aroma cookies tepung ampas tahu dan kacang hijau yang dihasilkan. Hal ini dikarenakan tidak adanya perubahan aroma cookies pada rasio tepung ampas tahu dan kacang hijau serta substitusi tepung terigu. Cookies dengan penambahan tepung ampas tahu dan kacang hijau serta substitusi tepung terigu menghasilkan aroma khas cookies.

\section{Rasa}

Rasa merupakan faktor penting dalam keputusan akhir konsumen untuk menerima atau menolak suatu produk pangan. (Agustina dkk., 2015). Nilai organoleptik rasa cookies tepung ampas tahu dan kacang hijau berkisar antara 1,75 (kurang suka) - 3,56 (suka) dengan rata-rata 2,96 (biasa). Hasil sidik ragam menunjukkan bahwa substitusi tepung terigu (T) berpengaruh sangat nyata $(\mathrm{P}<0,01)$ terhadap nilai organoleptik rasa cookies tepung ampas tahu dan kacang hijau yang dihasilkan. Sedangkan rasio tepung ampas tahu dan kacang hijau (K) serta interaksi keduanya (KT) berpengaruh tidak nyata $(\mathrm{P}>0.05)$ terhadap rasa cookies ampas tahu dan kacang hijau yng dihasilkan. Pengaruh substitusi tepung terigu (T) terhadap organoleptik rasa cookies dapat dilihat pada Gambar 5.

Berdasarkan hasil uji $\mathrm{BNT}_{0,01}$ (Gambar 5), menunjukkan bahwa nilai organoleptik rasa cookies tepung ampas tahu dan kacang hijau terendah diperoleh pada substitusi tepung terigu $(75 \%)$ yaitu $2,06 \%$. Sedangkan nilai orgaloleptik rasa tertinggi terdapat pada substitusi tepung terigu (50\%) yaitu 3,55 (suka), yang tidak berbeda dengan substitusi tepung terigu (25\%) yaitu 3,26 (biasa). Hal ini menunjukkan bahwa panelis lebih menyukai cookies dengan substitusi tepung terigu yang lebih rendah. Menurut Dwiyani (2013) Semakin banyak tepung terigu yang ditambahkan ke dalam adonan, akan meningkatkan jumlah protein sehingga rasa cookies lebih disukai panelis. Adanya protein yang terkandung pada terigu dapat menimbulkan reaksi maillard yang dapat memperbaiki rasa pada suatu bahan pangan. Hal ini sependapat dengan penelitian Simamora dkk. (2014) menyatakan bahwa semakin tinggi

Pengaruh Rasio Tepung Ampas Tahu dan Kacang Hijau serta Substitusi Tepung Terigu terhadap Mutu Cookies (Muhammad Fadhil, Martunis dan Anshar Patria)

Jurnal Ilmiah Mahasiswa Pertanian, Vol. 4, No. 1, Februari 2019: 517-526 
penggunaan tepung terigu pada cookies maka nilai hedonik rasa cookies kentang akan semakin meningkat.

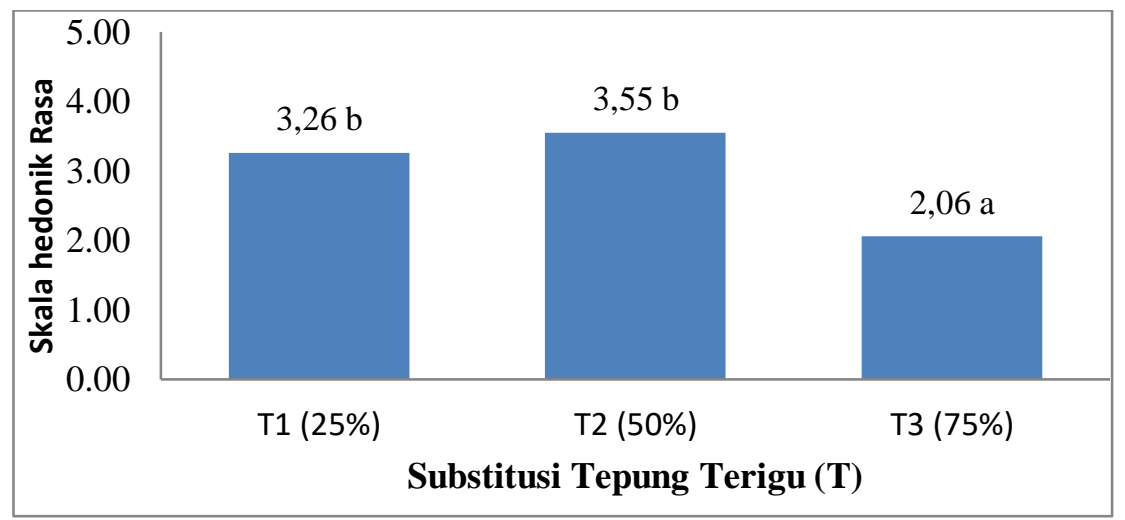

Gambar 5. Pengaruh substitusi tepung terigu (T) terhadap organoleptik rasa cookies $\left(\mathrm{BNT}_{0,01}\right.$ $=0,64$ dan $\mathrm{KK}=9,25 \%$, nilai yang diikuti oleh huruf yang sama menunjukkan perbedaan yang tidak nyata).

\section{Uji Organoleptik (Tekstur)}

Hasil uji hedonik tekstur cookies tepung ampas tahu dan kacang hijau berkisar antara 1,87 (kurang suka) - 3,37 (biasa) dengan rata-rata 2,78 (biasa). Hasil sidik yang diperoleh bahwa substitusi tepung terigu $(\mathrm{T})$ berpengaruh sangat nyata $(\mathrm{P}<0,01)$ terhadap tekstur cookies tepung ampas tahu dan kacang hijau. Sedangkan rasio tepung ampas tahu dan kacang hijau $(\mathrm{K})$ dan interaksi keduanya $(\mathrm{KT})$ tidak berpengaruh nyata $(\mathrm{P}>0,05)$ terhadap tekstur cookies tepung ampas tahu dan kacang hijau. Pengaruh substitusi tepung terigu (T) dapat dilihat pada Gambar 6.

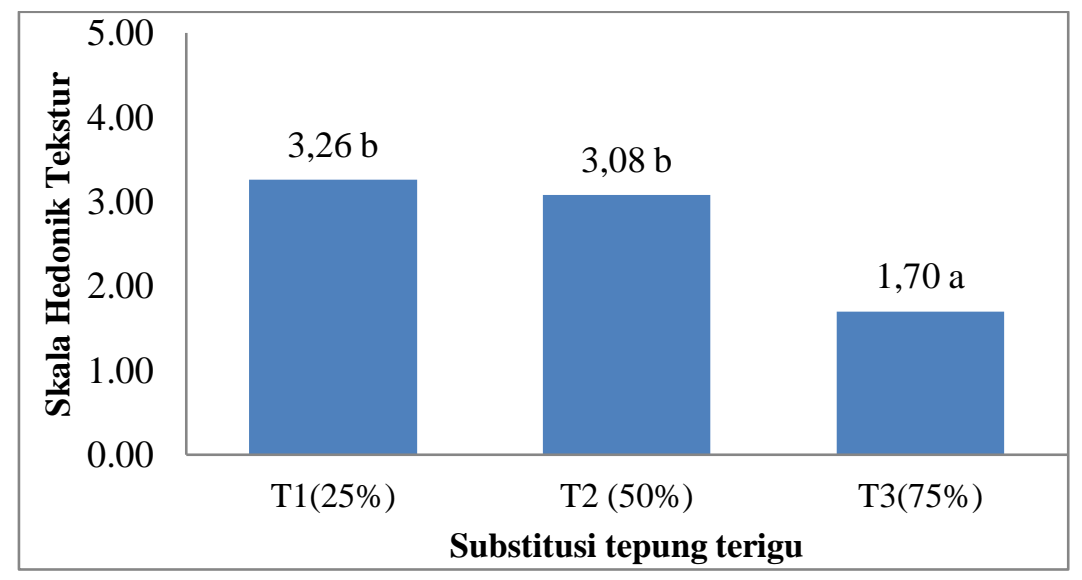

Gambar 6. Pengaruh substitusi tepung terigu (T) terhadap uji hedonik tekstur cookies tepung ampas tahu dan kacang hijau $\left(\mathrm{BNT}_{0,01}=0,88, \mathrm{KK}=13,49 \%\right.$, nilai yang diikuti oleh huruf yang sama menunjukkan perbedaan yang tidak nyata).

Bedasarkan hasil uji $\mathrm{BNT}_{0,01}$ (Gambar 6) menunjukan bahwa tekstur substitusi tepung terigu tertinggi terdapat pada substitusi $25 \%$ yaitu 3,26 (biasa) yang tidak berbeda nyata pada

Pengaruh Rasio Tepung Ampas Tahu dan Kacang Hijau serta Substitusi Tepung Terigu terhadap Mutu Cookies (Muhammad Fadhil, Martunis dan Anshar Patria)

Jurnal Ilmiah Mahasiswa Pertanian, Vol. 4, No. 1, Februari 2019: 517-526 
perlakuan substitusi tepung terigu 50\% yaitu 3,08 (biasa). Tetapi berbeda nyata dengan perlakuan substitusi tepung terigu $75 \%$ yaitu 1,70 (kurang suka). Semakin tinggi penggunan tepung terigu maka semakin tinggi tingkat kesukaan penelis terhadap produk cookies. Hal ini disebabkan karena tepung terigu memiliki sifat gluten dan gliadin yang tidak sama dengan jenis tepung lainnya. Fungsi tepung terigu yaitu membentuk adonan dan struktur kue, mempengaruhi warna, rasa, aroma dan tekstur saat pemanggangan (Ghozali dkk., 2013).

Hasil yang serupa diperoleh pada penelitian Satyatama (2012) yaitu semakin tinggi penggunaan tepung terigu maka tekstur brownies ampas tahu semakin lembut, hal ini dikarenakan persentase penggunaan tepung terigu lebih banyak. Perbedaan dari tekstur brownies tanpa substitusi lebih empuk dari pada brownies dengan subtitusi tepung ampas tahu. Gluten pada tepung terigu mempunyai kontribusi membentuk kerangka adonan yang akan membentuk cookies dengan tekstur yang renyah (Matz, 1992).

\section{Kadar Serat}

Berdasarkan perhitungan uji rangking dari hasil uji proksimat maka diperoleh perlakuan terbaik pada rasio tepung ampas tahu dan tepung kacang hijau (30:70) dengan substitusi tepung terigu (50\%). Cookies pada perlakuan ini dianalisis lebih lanjut terhadap kadar serat. Salah satu sifat kimia yang di analisis pada perlakuan terbaik cookies adalah serat kasar. Hasil analisis dapat dilihat pada Tabel 1.

Tabel 1. Hasil Analisis Cookies Perlakuan Terbaik

\begin{tabular}{lcc}
\hline Parameter Analisis & $\begin{array}{c}\text { Cookies pada rasio Tepung } \\
(30 \%: 70 \%) \text { dan substitusi } \\
\text { tepung terigu 50\% (K3T2) }\end{array}$ & $\begin{array}{c}\text { Pembanding } \\
\text { Berdasarkan penelitian } \\
\text { sebelumnya }\end{array}$ \\
\hline Kadar Serat Kasar (\%) & 3.66 & 3,23 (Wati, 2013)
\end{tabular}

Menurut SNI 01-2973 (2011), kadar serat pada cookies yaitu maksimal 0,5\%. Pada cookies ampas tahu dan tepung kacang hijau kadar serat yang dihasilkan melebihi SNI yaitu 3,66 \%. Tingginya kadar serat pada cookies dikarenakan pengaruh tepung pada pembuatan cookies. Menurut Daftar Komposisi Bahan Makanan (1995), Kandungan serat pada tepung ampas tahu yaitu 3,23\% dan tepung terigu 0,3\% sedangkan pada tepung kacang hijau yaitu 4,1\%. Tingginya kandungan serat pada tepung yang digunakan menghasilkan cookies yang tinggi serat. Menurut Suprapto (2004), selama pengolahan kadar serat kasar pada suatu produk menurun hal ini disebabkan oleh terurainya dinding sel bahan selama pengolahan. Selain itu, lama pengeringan juga dapat mempengaruhi penurunan kadar serat kasar bahan.

\section{KESIMPULAN DAN SARAN}

Berdasarkan hasil penelitian perlakuan terbaik diperoleh dari uji rangking proksimat pada rasio tepung ampas tahu dan kacang hijau (30\%:70\%) serta substitusi tepung terigu (50\%) (K3T2). yang menghasilkan kadar air 4,12 \%, kadar abu 2.04\%, kadar lemak 27,27\%, kadar serat kasar 3,66\%, kadar protein $22.11 \%$, karbohidrat $44,47 \%$ dan nilai organoleptik warna 3.40 (biasa), aroma 3,49 (biasa), rasa 3,56 (suka), dan tekstur 2,88 (biasa)

Pengaruh Rasio Tepung Ampas Tahu dan Kacang Hijau serta Substitusi Tepung Terigu terhadap Mutu Cookies (Muhammad Fadhil, Martunis dan Anshar Patria)

Jurnal Ilmiah Mahasiswa Pertanian, Vol. 4, No. 1, Februari 2019: 517-526 


\section{DAFTAR PUSTAKA}

Almatsier S. 2002. Prinsip Dasar Ilmu Gizi. Gramedia, Jakarta.

Agustina, Jumini dan Nurhayati. 2015. Pengaruh jenis Bahan Organik Terhadap Pertumbuhan dan Hasil Dua Varietas Tomat (Lycopersicum esculentum Mill L.). Jurnal Floratek 10: $46-53$

Cahyono. 2008. Kacang Hijau. Teknik Budidaya dan Analisis Usaha Tani. Aneka Ilmu. Semarang. Halaman : 122.

Hayati, S.R. 2014. Pembuatan Cookies dari Pasta Ubi Jalar Ungu (Ipomea batatas L.) dengan Penambahan Tepung Kacang Hijau. [Skripsi]. Universitas Syiah Kuala, Banda Aceh.

Ismanto, D,S., Aisman. 2013. Pengaruh Pencampuran Tepung Ampas Tahu Dan Tepung SaguTerhadap Mutu Nugget Ayam. Prosiding Seminar NasionalPeranan Teknologi Pangan dan Gizi Dalam Meningkatkan Mutu, Keamanan dan Kehalalan Produk Pangan Lokal.Fakultas Teknologi Pertanian Universitas Andalas Padang. Padang.

Khalid, A. 2010. Pengaruh Rasio Tepung Ampas Tahu dan Tepung Tapioka Serta Variasi Suhu Pemanggangan Terhadap Mutu Cookies. Skripsi. Prodi Teknologi Hasil Pertanian. Universitas Syiah Kuala, Banda Aceh.

Khuzrian, R. 2011. Pembuatan Teh Herbal dari Daun Kelor (Maringa oleifera L). [Skripsi]. Jurusan Teknologi Hasil Pertanian. Fakultas Pertanian Universitas Syiah Kuala, Banda Aceh.

Lutfi, M. 2007. Kajian Pembuatan Cookies Dengan Penambahan Bubur Bayam Merah (Ammaranthus Gangeticus) Sebagai Sumber Antioksiadan. Skripsi. Fakultas Pertanian. Universitas Syiah Kuala, Banda Aceh.

Lopulalan, C.G. 2008. Kajian Formulasi dan Isotherm Sorpsi Air Biskuit Jagung. Disertasi . Sekolah Pascasarjana. Institut Pertanian Bogor, Bogor.

Santoso, H. B. 1993. Pembuatan Tempe Dan Tahu Kedelai Bahan Makanan Bergizi Tingi. Kanisius, Yogyakarta.

Satyatama D. I. (2012). Pemanfaatan umbi talas sebagai bahan subtitusi tepung terigu dalam pembuatan cookies yang disuplementasi dengan kacang hijau. e-jurnal boga, Volume 2, Nomor 1. Hal :18 - 28.

Setiawan, E. B., 2011. Efektivitas Penambahan NaHCO3 Pada Pembuatan Tortilla Subsitusi Ampas Tahu. Skripsi. Universitas Pembangunan Nasional Veteran Jawa Timur, Surabaya.

Simamora. A., Ismed S., Era Y. 2014. Pengaruh Lama Pengeringan Kentang dan Perbandingan Tepung Terigu dan Tepung Kentang Terhadap Mutu Cookies Kentang. Jurna Rekayasa Pangan dan Pert., Vol.2 No.3 Hal 1-10.

Standar Nasional Indonesia. 2011. Biskuit dan Cookies Sni 01-2973. Badan Standarisasi Nasional, Jakarta.

Suarni, 2009. Prospek Pemanfaatan Tepung Jagung Untuk Kue Kering (Cookies). Jurnal Litbang Pertanian. Vol 2. Hal 28.

Wahyuni, E. A. D. 2006. Prospek Usaha dalam Pembuatan Kue Kering dari Tepung Biji Sorghum. Fakultas Teknik Universitas Negeri Semarang, Semarang.

Pengaruh Rasio Tepung Ampas Tahu dan Kacang Hijau serta Substitusi Tepung Terigu terhadap Mutu Cookies (Muhammad Fadhil, Martunis dan Anshar Patria)

Jurnal Ilmiah Mahasiswa Pertanian, Vol. 4, No. 1, Februari 2019: 517-526 